\title{
PENGKAJIAN PEMUPUKAN FOSFOR (P) DAN KALIUM (K) BERDASARKAN STATUS HARA PADA TANAH DI DAERAH PERTANAMAN JAGUNG DI KABUPATEN PASAMAN BARAT
}

\author{
Yulinar Zubaidah \\ BPTP Sukarami Solok
}

\begin{abstract}
Analysis of phosphorous $(\mathrm{P})$ and potassium $(\mathrm{K})$ fertilization based on soil $\mathrm{P}$ and $\mathrm{K}$ status at maize planting area in Pasaman Barat regency had done on October until December 2005. The research was conducted by using survey method. The area was surveyed through some trails. Soil samples were taken in every $500-1000 \mathrm{~m}$ in distance. Global Position System (GPS) was used to determine the coordinates of sampling points. In each point composite bulk soil samples were taken on the top $20 \mathrm{~cm}$ soil depth. Each sample represented about 50 ha area. The results showed that from 7702.2 ha area surveyed, there was 5351.5 ha $(69.4 \%)$ of the area having high P content, $1487.5 \mathrm{Ha} \mathrm{(19,3 \% )} \mathrm{having} \mathrm{moderate} \mathrm{P,} \mathrm{and} 863.2$ Ha $(11,2 \%)$ having low P. Potassium status of the soil in the area was as follows, $2798.4 \mathrm{Ha}$ $(36,3 \%)$ having high $\mathrm{K}, 4499.4 \mathrm{Ha}(58,4 \%)$ having moderate $\mathrm{K}$, and $404.4 \mathrm{Ha}(5,2 \%)$ having low K. The requirement of SP-36 fertilizer was about $90 \mathrm{~kg} / \mathrm{Ha}, 250 \mathrm{~kg} / \mathrm{Ha}$ and $500 \mathrm{~kg} / \mathrm{Ha}$, for soil having high $\mathrm{P}$, moderate $\mathrm{P}$, and low $\mathrm{P}$ content. Potassium was required about $0 \mathrm{~kg} \mathrm{KCl} / \mathrm{Ha}$, $50 \mathrm{~kg} \mathrm{KCl} / \mathrm{Ha}$ and $250 \mathrm{~kg} \mathrm{KCl} / \mathrm{Ha}$, for soil having high $\mathrm{K}$, moderate $\mathrm{K}$, and low $\mathrm{K}$, respectively. The both fertilization recommendation was the amount of SP36 and $\mathrm{KCl}$ to reach production about 4,5 ton dry weight corn kernel (with water content 14\%) or it is equal to 8 ton corn weight during harvesting time (with water content $25 \%$ ).
\end{abstract}

\section{Key Words: P- soil status, K-soil status, fertilizer recommendation}

\section{PENDAHULUAN}

Produksi tanaman pada umumnya ditentukan oleh 2 faktor yaitu luas panen dan produktivitas tanaman itu sendiri. Peningkatan produksi harus bertitik tolak dari kedua faktor tersebut (Puslitbangtan, 2002). Bila perluasan areal menjadi kendala, peningkatan produksi dapat dicapai dengan peningkatan produktivitas tanaman itu sendiri dengan cara meningkatkan kesuburan tanah melalui pemupukan, pemakaian varietas unggul, pencegahan hama penyakit, pemeliharaan, pengairan dan lain-lainnya.

Tahun 2004 Sumatera Barat membutuhkan jagung sebagai pakan ternak mencapai 115.675 ton, sedangkan produksi jagung tahun 2004 baru mencapai 99.336 ton. Sumatera Barat masih perlu untuk meningkatkan produksi jagung untuk kebutuhan pakan ternak, ditambah untuk mencukupi kebutuhan masyarakat akan jagung. Pemda Sumatera Barat telah menetapkan Kabupaten Pasaman Barat dan unsur fosfor (P) dan Kalium (K) dalam tanah. Fosfor dalam tanah bersumber dari P- fosfor tanah, $\mathrm{P}$ yang berasal dari residu tanaman dan P yang berasal dari pupuk. Ketersediaan Pesisir Selatan sebagai daerah pengembangan jagung. Dengan luas areal 13.175 Ha untuk Pasaman Barat dan 13.000 Ha untuk Pesisir Selatan. (Diperta Horti, 2004).

Kabupaten Pasaman Barat melalui Dinas Pertanian dan Peternakan, telah mensurvei lahan-lahan yang potensial untuk tanaman jagung terutama unsur fosfor $(\mathrm{P})$ dan Kalium (K). Hal ini dilakukan karena bila dilihat produksi jagung di sentra-sentra produksi jagung dari tahun 1999 s/d 2004 sudah mulai stabil, sudah tidak ada lagi peningkatan maupun penurunan hasil yang signifikan. Hasil rata-rata jagung per Ha di Pasaman Barat sejak tahun 1999 s/d 2003 berturut-turut 5,73 ton; 4,81 ton; 5,03 ton; 5,58 ton dan 5,35 ton (Bappeda Tk II Pasaman 1999 s/d 2003 dan Bappeda Pasaman Barat 2003 dan 2004). 
Turunnya hasil antara lain disebabkan sudah menurunnya tingkat kesuburan tanah. Diantaranya berkurangnya ketersediaan $\mathrm{P}$ dalam tanah sangat ditentukan oleh $\mathrm{pH}$ tanah. Fosfor (P) akan tersedia cukup bagi tanaman pada kisaran pH 5,5 sampai 6,5 (Buckman \& Brady, 1964). Kemudian oleh Aluminium (Al) dan Besi (Fe).

Pada tanah dengan $\mathrm{pH}$ sangat masam $(\mathrm{pH}<5) \mathrm{P}$ akan diendapkan dalam bentuk $\mathrm{Al}(\mathrm{OH})_{2} \mathrm{H}_{2} \mathrm{PO}_{4} \quad \downarrow$ dan $\mathrm{Fe}(\mathrm{OH})_{2} \mathrm{H}_{2} \mathrm{PO}_{4} \quad \downarrow$. Bentuk ini tidak dapat diambil oleh tanaman (Buckman \& Brady, 1964). Kadar bahan organik tanah juga sangat mempengaruhi ketersediaan unsur Fosfor (P). Pada kondisi bahan organik cukup unsur $\mathrm{Al}$ dan $\mathrm{Fe}$ akan dicelak oleh bahan organik sehingga unsur Forfor (P) akan dapat diambil oleh tanaman. Pada tanah Andosal $\mathrm{P}$ yang diikat oleh mineral Allofan (P-retensi) juga sulit tersedia bagi tanaman. Disamping unsur fosfor $(\mathrm{P})$, kalium $(\mathrm{K})$ sangat penting bagi pertumbuhan tanaman. Ketersediaan kalium (K) sangat dipengaruhi oleh curah hujan. Kalium (K) sangat mudah hilang lewat pelindihan (pencucian). Di daerah tropik (Kabupaten Pasaman Barat) kehilangan kalium $(\mathrm{K})$ akibat pelindihan lebih dominan, sehingga kalium $(\mathrm{K})$ tersedia atau tertukar menjadi rendah. Untuk mendapatkan produksi optimal dibutuhkan pemupukan kalium (K). Aerasi tanah juga sangat menentukan dalam pengambilan kalium oleh tanaman jagung. Pada kandungan air tanah $40 \%$ pengambilan kalium $(\mathrm{K})$ oleh tanaman jagung hanya $45 \%$, dibandingkan dengan pengambilan pada kadar air $15 \%$ sebesar $100 \%$ (Forth, 1988). Pasaman Barat termasuk tipe iklim A dengan jumlah bulan basah (> $100 \mathrm{~mm} /$ bulan) lebih dari 9 bulan/tahun dan jumlah bulan kering $(<100$ $\mathrm{mm} / \mathrm{bulan}$ ) kecil dari 2 bulan (Oldeman,
1979), akan menyebabkan reaksi tanah $(\mathrm{pH})$ akan masam sampai sangat masam sehingga ketersediaan $\mathrm{P}$ akan semakin sedikit dan pelindian unsur kalium (K) akan semakin meningkat dari tahun ke tahun.

Penelitian bertujuan untuk mengetahui status unsur $\mathrm{P}$ dan $\mathrm{K}$ tanah dan memberikan rekomendasi pemupukan $\mathrm{P}$ dan $\mathrm{K}$ berdasarkan status $\mathrm{P}$ dan $\mathrm{K}$ tanah untuk daerah pertanaman jagung di Kabupaten Pasaman Barat.

\section{BAHAN DAN METODA}

Pengkajian dilaksanakan di tiga Kecamatan di Kabupaten Pasaman Barat yaitu Kecamatan Kinali, Kecamatan Luhak Nan Duo dan Kecamatan Pasaman. Ketiga kecamatan ini merupakan sentra pertanaman jagung di Kabupaten Pasaman Barat.

Pengkajian dirancang dalam bentuk survey dengan metoda penjelajahan seluruh daerah survey melalui rintisan (jalur pengamatan). Pada hamparan yang luas, pengambilan contoh tanah diatur melalui jalur-jalur dengan jarak 500-1000 m. titik pengambilan contoh tanah tiap $500 \mathrm{~m}$ dengan jarak jalur $1000 \mathrm{~m}$, sehingga titik pengamatan mewakili luas daerah survey 50 Ha. Penentuan koordinat dan jarak titik pengambilan contoh tanah dipakai alat GPS (Global Position System). Pengambilan contoh tanah di lapangan dengan memakai metoda Bulk Komposit. Contoh tanah diambil pada lapisan topsoil kedalaman 0-20 $\mathrm{cm}$. beberapa contoh tanah individu digabung, diaduk sampai homogen (tercampur merata) dan kemudian diambil kira-kira $1 \mathrm{~kg}$ sebagai contoh untuk dianalisa unsur fosfor (P) dan kalium (K). Satu contoh tanah yang telah diaduk mewakili luas daerah survey pertanaman jagung seluas 50

Tabel 1. Jumlah contoh tanah pada masing-masing daerah survai (Gambar 1).

\begin{tabular}{clcc}
\hline No & \multicolumn{1}{c}{ Kecamatan } & $\begin{array}{c}\text { Luas daerah } \\
\text { survey (Ha) }\end{array}$ & $\begin{array}{c}\text { Jumlah contoh } \\
\text { tanah (bh) }\end{array}$ \\
\hline 1 & Pasaman & 963,1 & 26 \\
2 & Luhak Nan Duo & 1736,4 & 36 \\
3 & Kinali & 5002,7 & 35 \\
\hline
\end{tabular}


Ha. Dasar pengambilan contoh tanah berdasarkan Land unit (satuan lahan). Di samping itu juga diperhatikan topografi, lereng, vegetasi, lingkungan dan perlakuan yang telah diberikan

Tingkat survey tanah adalah semi detail dan peta yang dihasilkan adalah peta status hara $\mathrm{P}$ dan $\mathrm{K}$. Peta dasar yang digunakan adalah peta topografi skala 1 : 50.000 (soil survey staff, 1993). Rekomendasi pemupukan dengan cara menghitung kebutuhan P (SP36) dan pupuk $\mathrm{K}(\mathrm{KCl})$ dengan proyeksi produksi jagung 4,5 ton pipilan kering (k.a 14\%) dan setara dengan 8,0 ton pipilan kering panen (k.a 25 $\%$ ) pada masing-masing satuan peta.

\section{HASIL DAN PEMBAHASAN}

Secara administratif, daerah survey terletak di kecamatan Pasaman, Luhak Nan Duo dan Kinali, secara geografis Kabupaten Pasaman terletak pada $99^{\circ}, 5^{\prime}-100^{\circ}, 05^{\prime}$ bujur timur dan $0^{0}, 10^{\prime}-0^{0}, 35^{\prime}$ lintang selatan sedangkan daerah survey Kecamatan Pasaman terletak pada $99^{\circ}, 15^{\prime}-99^{0}, 51^{\prime}$ bujur timur dan $0^{0}, 15^{\prime}-99^{0}, 59^{\prime}$ lintang selatan, Kecamatan Luhak Nan Duo $99^{0}, 44^{\prime}-99^{0}, 59^{\prime}$ bujur timur dan $0^{0}, 02^{\prime}-0^{0}, 07^{\prime}$ lintang selatan, Kecamatan Kinali terletak pada $99^{\circ}, 45^{\prime}-99^{\circ}$, 69' bujur timur dan $0^{0}, 01^{\prime}-0^{0}, 03^{\prime}$ lintang selatan. Berdasarkan peta geologi Sumatera yang disusun lembaga penelitian tanah Bogor (1979) daerah survey ini terdiri atas formasi batuan endapan (Aluvium) trias dan bahan vulkanik yang berasal dari gunung Talamau dan Pasaman yang menjadi bahan induk tanah di daerah ini. Daerah survey merupakan daerah dengan iklim type A (Oldeman, 1979), dimana bulan basah (>100 $\mathrm{mm} /$ bulan) lebih dari 9 bulan/ tahun dan jumlah bulan kering $(<100 \mathrm{~mm} /$ bulan) kecil dari 2 bulan/ tahun.

Dari hasil analisis laboratorium di daerah survey dijumpai fosfor $(\mathrm{P})$ dan kalium $(\mathrm{K})$ berkisar dari tinggi sampai rendah. Kadar fosfor $(\mathrm{P})$ berkisar dari 61,0 ppm - 11,4 ppm $\mathrm{P}_{2} \mathrm{O}_{5}$ dan kalium $(\mathrm{K})$ berkisar dari 1,86 me/100 g - 0,19 me/100 g $\mathrm{K}_{2} \mathrm{O}$. Unsur fosfor (P) tinggi dijumpai disemua Kecamatan meliputi luas 5351,5 Ha atau $69,4 \%$ dan yang terluas dijumpai di Kecamatan Kinali dengan total luas 2891,2
Ha dari total daerah survey atau 37,5\%, Kecamatan Luhak Nan Duo 1681,5 Ha atau 21,8\% dan sedikit dijumpai di Kecamatan Pasaman dengan total luas $778,8 \mathrm{Ha}$ atau $10,1 \%$ dari total luas daerah survey. Tingginya kandungan fosfor $(\mathrm{P})$ di Kecamatan Kinali ini diduga karena pemberian pupuk $\mathrm{P}$ yang intensif selama pertanaman jagung, pengaruh bahan induk tanah yang berasal dari kipasan abu vulkanik dan tambahan bahan yang terangkut dari Batang Mandi Angin, Masang Gadang dan Batang Kinali. Walaupun demikian unsur fosfor (P) adalah unsur yang hanya sedikit sekali yang dapat diserap tanaman yaitu \pm 20 $\%$ selebihnya tinggal di dalam tanah dalam bentuk terikat dan sebagian lagi hilang melalui air perkolasi (Soepardi, 1974 ; Forth, 1988).

Disamping daerah Pasaman Barat termasuk type iklim A dengan jumlah bulan basah (> $100 \mathrm{~mm} /$ bulan) lebih dari 9 bulan/ tahun. Sehingga kehilangan unsur dari dalam tanah akan meningkat dari tahun ke tahun (Oldeman, 1979). Daerah dengan kandungan fosfor $(\mathrm{P})$ sedang meliputi luas $1487,5 \mathrm{Ha}$ atau $19,3 \%$ dari total luas daerah yang disurvey. Terluas terdapat di Kecamatan Kinali yaitu 1248,3 Ha atau 15,2 $\%$ dari total luas daerah yang disurvey, terutama tersebar di daerah Sidodadi dan Kola.

Daerah dengan kandungan fosfor $(\mathrm{P})$ rendah mencakup luas 863,2 $\mathrm{Ha}$ atau $11,2 \%$. Daerah dengan kandungan fosfor $(\mathrm{P})$ rendah hanya terdapat di Kecamatan Kinali yaitu daerah Sidodadi. Rendahnya kandungan P di daerah ini diduga karena daerah tersebut merupakan daerah cekungan dan bahan induk tanah lebih didominasi oleh bahan organik, ini terlihat secara visual di lapangan. (Tabel 2)

Status kalium (K) dengan kriteria tinggi, meliputi luas 2798,4 $\mathrm{Ha}$ atau 36,3 \% dari total luas daerah survey, terluas di dapati di Kecamatan Kinali. Hampir diseluruh lokasi survey, kecuali daerah Sidodadi. Tingginya kalium (K) diduga karena daerah ini terletak di daerah tanggul dan kipasan aliran dari sungai-sungai yang ada di daerah tersebut seperti Batan Mandi Angin, Batang Kinali, Batang Banul dan lain-lain. Kalium dengan kriteria sedang 
meliputi luas 4499,4 $\mathrm{Ha}$ atau $58,4 \%$ dari total daerah survey terluas terdapat di Kecamatan Kinali seluas 3148,1 Ha atau
$48,8 \%$. Kalium dengan kriteria rendah meliputi luas 404,4 Ha atau 5,2\% dari total

Tabel 2. Status unsur hara fosfor (P) di Kecamatan Pasaman, Luhak Nan Duo, dan Kinali Kabupaten Pasaman Barat.

\begin{tabular}{|c|c|c|c|c|}
\hline \multirow{2}{*}{ No } & \multirow{2}{*}{$\begin{array}{c}\text { Status Hara } \\
\text { P }\end{array}$} & \multirow{2}{*}{ Kecamatan } & \multicolumn{2}{|c|}{ Luas } \\
\hline & & & $\mathrm{Ha}$ & $\%$ \\
\hline \multirow{4}{*}{1} & \multirow{4}{*}{ Tinggi } & Pasaman & 778,8 & 10,1 \\
\hline & & Luhak nan duo & 1681,5 & 21,8 \\
\hline & & Kinali & 2891,2 & 37,5 \\
\hline & & Jumlah & 5351,5 & 69,4 \\
\hline \multirow{4}{*}{2} & \multirow{4}{*}{ Sedang } & Pasaman & 184,3 & 2,4 \\
\hline & & Luhak nan duo & 54,9 & 0,7 \\
\hline & & Kinali & 148,3 & 16,2 \\
\hline & & Jumlah & 1477,5 & 19,3 \\
\hline \multirow{5}{*}{3} & \multirow{5}{*}{ Rendah } & Pasaman & 0,0 & 0.0 \\
\hline & & Luhak nan duo & 0,0 & 0,0 \\
\hline & & Kinali & 863,2 & 11,2 \\
\hline & & Jumlah & 863,2 & 11,2 \\
\hline & & Total & 7702,2 & 100,0 \\
\hline
\end{tabular}

Tabel 3. Status unsur hara kalium (K) di Kecamatan Pasaman, Luhak Nan Duo, dan Kinali Kabupaten Pasaman Barat.

\begin{tabular}{|c|c|c|c|c|}
\hline \multirow{2}{*}{ No } & \multirow{2}{*}{$\begin{array}{c}\text { Status Hara } \\
\text { K }\end{array}$} & \multirow{2}{*}{ Kecamatan } & \multicolumn{2}{|c|}{ Luas } \\
\hline & & & $\mathrm{Ha}$ & $\%$ \\
\hline \multirow[t]{4}{*}{1} & K-Tinggi & Pasaman & 279,0 & 3,6 \\
\hline & & Luhak nan duo & 664,8 & 8,6 \\
\hline & & Kinali & 1854,6 & 24,1 \\
\hline & & Jumlah & 2798,4 & 36,3 \\
\hline \multirow[t]{4}{*}{2} & K-Sedang & Pasaman & 388,2 & 5,1 \\
\hline & & Luhak nan duo & 963,1 & 12,5 \\
\hline & & Kinali & $31,48,1$ & 40,8 \\
\hline & & Jumlah & 4499,4 & 58,4 \\
\hline \multirow[t]{5}{*}{3} & K-Rendah & Pasaman & 295,9 & 3,8 \\
\hline & & Luhak nan duo & 108,5 & 1,4 \\
\hline & & Kinali & 0,0 & 0,0 \\
\hline & & Jumlah & 404,4 & 5,2 \\
\hline & & Total & 7702,2 & 100 \\
\hline
\end{tabular}


daerah survey. Daerah dengan kalium (K) rendah yaitu Kecamatan Pasaman dan Kecamatan Luhak Nan Duo, yaitu di daerah Pujarah, Cubadak dan Suka Menanti (tabel $3)$.

Rendahnya kandungan kalium (K) di daerah ini diduga dipengaruhi bahan induk tanah yaitu batuan beku masam dengan mineral dominan felspar, kwarsa dan sedikit plagioklas dan biotip.

Dari hasil analisis unsur $\mathrm{P}$ dan $\mathrm{K}$ didapatkan tujuh satuan peta (Tabel 4, peta 2). Satuan peta satu (SP1) merupakan daerah yang mengandung $\mathrm{P}$ dan K-tinggi. Daerah ini meliputi luas $2545,9 \mathrm{Ha}$ atau $33 \%$ dari total luas daerah yang disurvey. Terluas di Kecamatan Kinali, Luhak Nan Duo dan terendah di Kecamatan Pasaman. Satuan peta 2 (SP2) merupakan daerah dengan kadar P-tinggi dan K-sedang. Daerah ini meliputi luas 2451,6 $\mathrm{Ha}$ atau $31,8 \%$ dari total luas daerah yang disurvey, satuan peta 2 ini dijumpai di ketiga Kecamatan, terluas di Kecamatan Kinali, kemudian Kecamatan Luhak Nan Duo dan terkecil Kabupaten Pasaman (Tabel 4. peta 2). Satuan peta 3 (SP 3) merupakan aera dengan kadar P-tinggi dan K-rendah. Luas daerah ini meliputi $354,0 \mathrm{Ha}$ atau $4,6 \%$ dari total luas daerah yang disurvey.

Satuan peta ini terdapat di dua kecamatan yaitu di Kecamatan Pasaman dan Kecamatan Luhak Nan Duo (Tabel 4 dan peta 2). Satuan peta 4 (SP4) lahan dengan kandungan pada K-sedang. Satuan peta ini meliputi luas $1184,6 \mathrm{Ha}$ atau $15,4 \%$ dari total daerah yang disurvey. Terluas di Kecamatan Kinali, kemudian Kecamatan Pasaman dan terkecil Kecamatan Luhak Nan Duo (Tabel 4 dan peta 2). Satuan peta 5 (SP5) merupakan lahan daya kandungan Psedang dan K-tinggi. Satuan peta ini meliputi luas 252,5 $\mathrm{Ha}$ atau 6,6\% dari total luas daerah survey. Tersebar di Kecamatan Kinali dan Pasaman (Tabel 4 dan peta 2). Satuan peta 6 (SP6) daerah dengan kandungan P-sedang dan K-rendah. Satuan peta ini seluas 50,4 Ha atau 0,6\% dan hanya terdapat di Kecamatan Pasaman (Tabel 4 dan peta 2). Satuan peta 7 (SP7) daerah dengan kadar P-rendah dan K-sedang. Satuan peta ini hanya terdapat di Kecamatan
Kinali di daerah Sidodadi seluas 863,2 Ha atau $11,3 \%$ dari total daerah survey.

Kebutuhan pupuk P (SP36) dan pupuk $\mathrm{K}$ (kcl) dihitung berdasarkan interpretasi produksi jagung 4,5 ton pipilon kering (k.a $14 \%$ ) dan setara dengan 8,0 ton pipilon kering (k.a $25 \%$ ) per Ha. Untuk lahan yang berstatus P-tinggi dibutuhkan pupuk SP 36 $90 \mathrm{~kg} / \mathrm{ha}$. Walau status P-tinggi bukan tidak dibutuhkan lagi pupuk $\mathrm{P}$, karena tanaman jagung merupakan tanaman yang rakus dengan unsur P. Bila terjadi sedikit saja kekurangan $\mathrm{P}$ dalam tanah, maka tanaman akan langsung mengalami defisiensi $\mathrm{P}$ yang ditunjukan dengan gejala daun kerdil dan tulang berwarna ungu, bila sudah terbentuk tongkol maka pembentukan biji tidak sempurna (Purwowidodo, 1992).

$P$ dalam tanah tidak banyak yang dapat diserap oleh tanaman hanya $\pm 20 \%$, selebihnya akan hilang lewat air perkolasi dan sebagian lagi terikat dalam tanah (Forth, 1988, Soepardi, 1975). Penyerapan P oleh tanaman sangat dipengaruhi oleh PH tanah, kapasitas tukar kation (KTK), kandungan bahan organik dan lain-lainnya. Bila faktorfaktor ini dapat diminilisasi maka takaran 90 kg SP36 dapat dikurangi.

Lahan dengan kandungan $\mathrm{P}$ sedang membutuhkan pupuk SP36 sebanyak 250 $\mathrm{kg} / \mathrm{ha}$. Bila faktor-faktor pembatas $(\mathrm{PH}$, KTK, bahan organik) dapat ditingkatkan maka jumlah/ takaran pupuk SP 36 dapat dikurangi dari $250 \mathrm{~kg} \mathrm{SP} 36 / \mathrm{ha}$.

Lahan dengan kadar P-rendah membutuhkan pupuk SP36 sebanyak 500 $\mathrm{kg} / \mathrm{ha}$. Luas lahan ini lebih sedikit $(11,2 \%)$. Takaran inipun dapat dikurangi bila dibarengi dengan peningkatan $\mathrm{PH}$ (pemberian pupuk kapur) dan bahan organik sebagai ameliorasi lahan.

Kebutuhan pupuk Kcl untuk lahan dengan kadar K-tinggi, tidak dibutuhkan lagi pupuk $\mathrm{Kcl} \quad\left(\begin{array}{lll}0 & \mathrm{~kg} & \mathrm{Kal} / \mathrm{ha}\end{array}\right)$. Walaupun demikian karena kalium (K) mudah hilang di dalam tanah, karena sifatnya yang mobil, perlu juga diberikan pupuk kalium sebanyak $25-50 \mathrm{~kg} \mathrm{Kcl} / \mathrm{ha}$. Kalium (K) sangat dibutuhkan tanaman dalam pertumbuhan dan produksi seperti pembentukan pati dan protein, proses membuka dan menutup stomata, memperluas permukaan akar, ketahanan tanaman tanaman terhadap 
Tabel 4. Satuan peta, status unsur hara P dan K di Kecamatan Pasaman, Luhak Nan Duo dan Kinali, Kabupaten Pasaman Barat (Gambar 1).

\begin{tabular}{|c|c|c|c|c|c|}
\hline \multirow{2}{*}{ No } & \multirow{2}{*}{ Simbol } & \multirow{2}{*}{ Uraian Satuan Peta } & \multirow{2}{*}{ Kecamatan } & \multicolumn{2}{|c|}{ luas } \\
\hline & & & & $\mathrm{Ha}$ & $\%$ \\
\hline \multirow{4}{*}{1} & \multirow{4}{*}{$\mathrm{T} / \mathrm{T}$} & Kadar $\mathrm{P}$ adalah tinggi & Pasaman & 212,8 & \\
\hline & & $\left(>35 \mathrm{ppm} \mathrm{P}_{2} \mathrm{O}_{5}\right.$ ) dan & Luhak nan duo & 664,8 & \\
\hline & & $\mathrm{K}$-tinggi $(>0,5 \mathrm{me} / 100 \mathrm{~g}) \mathrm{K} 2 \mathrm{O}$ & Kinali & 1628,3 & \\
\hline & & Jumlah & & 2545,9 & 33,0 \\
\hline \multirow{4}{*}{2} & \multirow{4}{*}{$\mathrm{T} / \mathrm{S}$} & Kadar $\mathrm{P}$ adalah tinggi & Pasaman & 320,5 & \\
\hline & & $\left(>35 \mathrm{ppm} \mathrm{P}_{2} \mathrm{O}_{5}\right)$ dan & Luhak nan duo & 908,2 & \\
\hline & & K-sedang (> 0,3-0,5 me/100 g) K2O & Kinali & 1222,7 & \\
\hline & & Jumlah & & 2451,6 & 31,8 \\
\hline \multirow{4}{*}{3} & \multirow{4}{*}{$\mathrm{T} / \mathrm{R}$} & Kadar P-tinggi (> 35 ppm $\mathrm{P}_{2} \mathrm{O}_{5}$ ) & Pasaman & 245,6 & \\
\hline & & dan K-rendah & Luhak nan duo & 108,5 & \\
\hline & & $(>0,3 \mathrm{me} / 100 \mathrm{~g}) \mathrm{K} 2 \mathrm{O}$ & Kinali & 0,0 & \\
\hline & & Jumlah & & 354,1 & 4,6 \\
\hline \multirow{4}{*}{4} & \multirow{4}{*}{$\mathrm{S} / \mathrm{S}$} & Kadar P-sedang (15-35 ppm) & Pasaman & 67,7 & \\
\hline & & $\mathrm{P}_{2} \mathrm{O}_{5}, \mathrm{~K}$-sedang & Luhak nan duo & 54,9 & \\
\hline & & $(>0,3-0,5 \mathrm{me} / 100 \mathrm{~g}) \mathrm{K} 2 \mathrm{O}$ & Kinali & 1062,0 & \\
\hline & & Jumlah & & 1184,6 & 15,4 \\
\hline \multirow{4}{*}{5} & \multirow{3}{*}{$\mathrm{S} / \mathrm{T}$} & \multirow{3}{*}{$\begin{array}{l}\text { Kadar P-sedang }(15-35 \mathrm{ppm}) \mathrm{P}_{2} \mathrm{O}_{5} \text { dan } \\
\text { K-tinggi } \\
(>0,5 \mathrm{me} / 100 \mathrm{~g}) \mathrm{K} 2 \mathrm{O}\end{array}$} & Pasaman & 66,2 & \\
\hline & & & Luhak nan duo & 0,0 & \\
\hline & & & Kinali & 186,3 & \\
\hline & & Jumlah & & 252,5 & 3,3 \\
\hline \multirow{4}{*}{6} & \multirow{3}{*}{$\mathrm{S} / \mathrm{R}$} & \multirow{3}{*}{$\begin{array}{l}\text { Kadar P-sedang (15-35 ppm) } \mathrm{P}_{2} \mathrm{O}_{5} \text { dan } \\
\text { K-rendah }(>0,3 \mathrm{me} / 100 \mathrm{~g}) \mathrm{K} 2 \mathrm{O}\end{array}$} & Pasaman & 50,4 & \\
\hline & & & Luhak nan duo & 0,0 & \\
\hline & & & Kinali & 0,0 & \\
\hline & & Jumlah & & 50,4 & 0,6 \\
\hline \multirow{5}{*}{7} & \multirow{5}{*}{$\mathrm{R} / \mathrm{S}$} & Kadar P-rendah (<15 ppm) & Pasaman & 0,0 & \\
\hline & & $\mathrm{P}_{2} \mathrm{O}_{5}$, dan $\mathrm{K}$-sedang & Luhak nan duo & 0,0 & \\
\hline & & $(>0,3-0,5 \mathrm{ml} / 100 \mathrm{~g}) \mathrm{K} 20$ & Kinali & 863,2 & \\
\hline & & Jumlah & & 863,2 & 11,3 \\
\hline & & Total & & 7702,2 & 100 \\
\hline
\end{tabular}




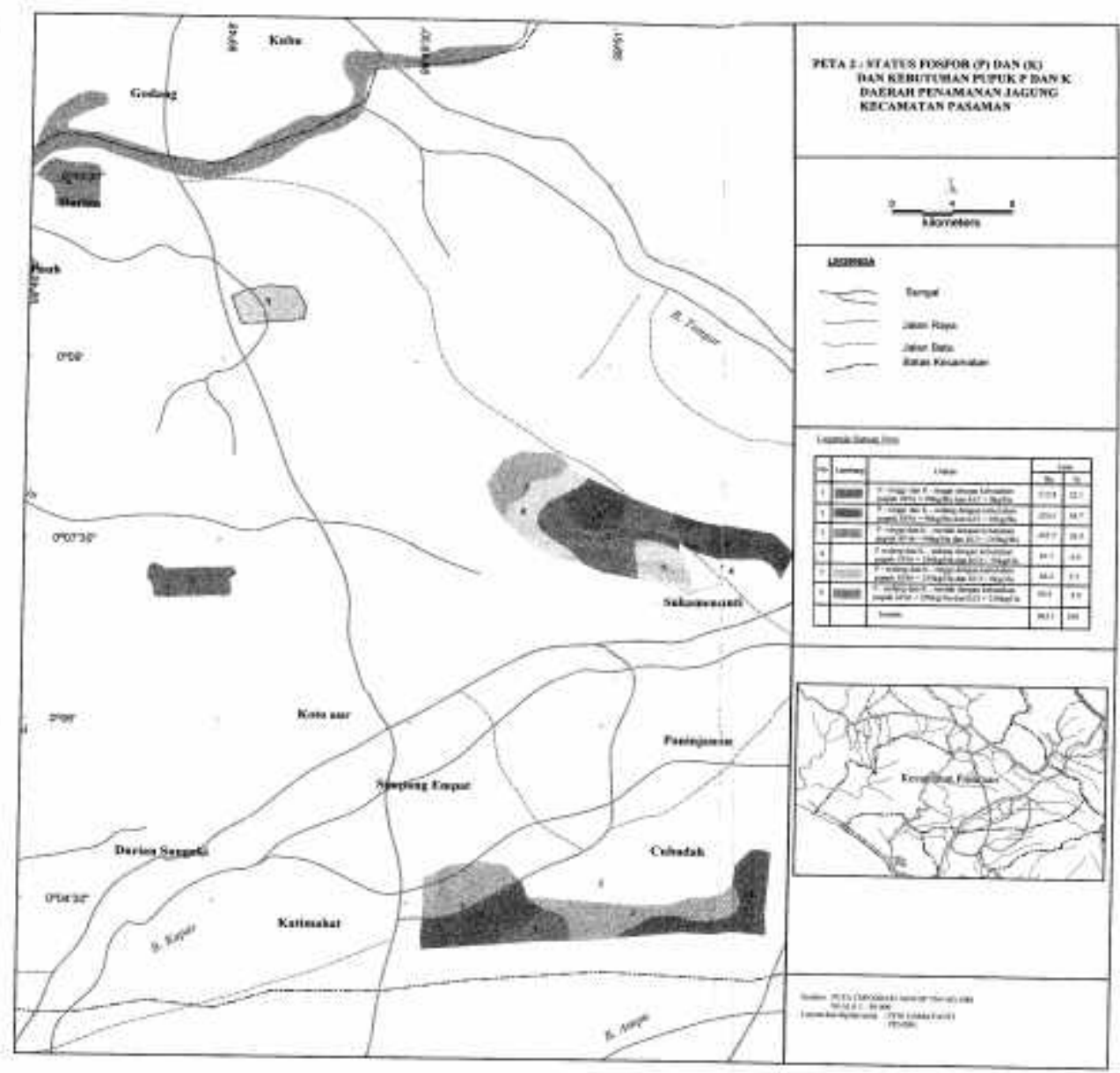

Gambar 1. Peta status pospor dan kalium serta kebutuhan pupuk P dan K daerah penanaman jagung Kecamatan Pasaman

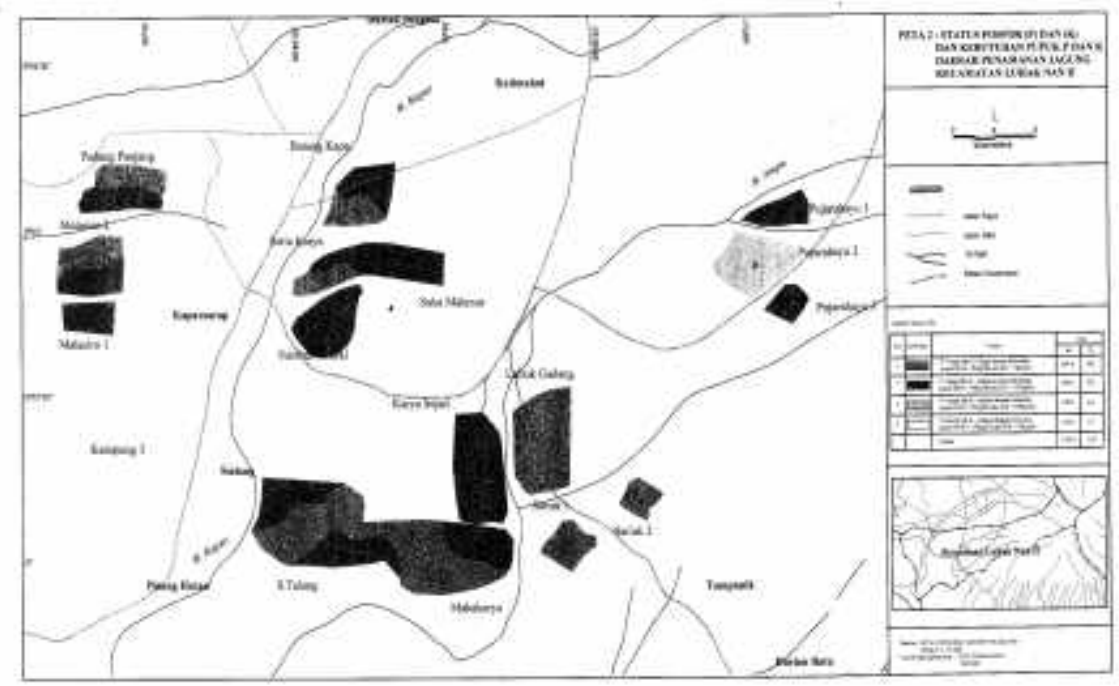

Gambar 2. Peta status pospor dan kalium serta kebutuhan pupuk P dan K daerah penanaman jagung Kecamatan Luhak Nan Duo 


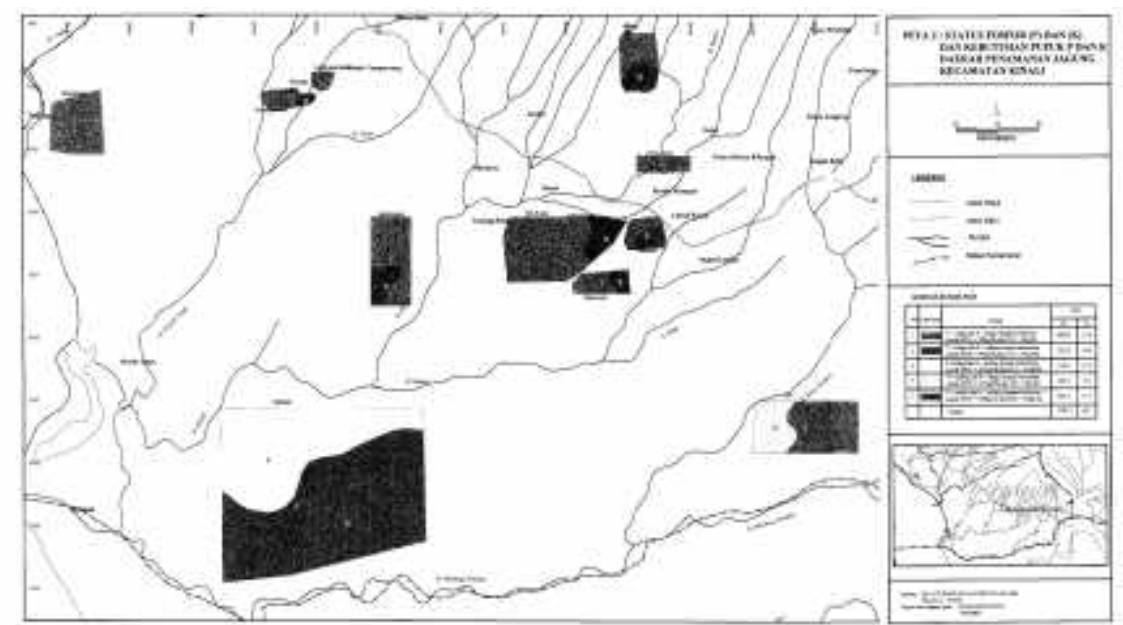

Gambar 3. Peta status pospor dan kalium serta kebutuhan pupuk $\mathrm{P}$ dan $\mathrm{K}$ daerah penanaman jagung Kecamatan Kinali

Tabel 5. Rekomendasi pupuk $\mathrm{P}$ dan $\mathrm{K}$ untuk tanaman jagung berdasarkan status $\mathrm{P}$ dan $\mathrm{K}$ tanah di Kecamatan Pasaman, Luhak Nan Duo, Kinali, Kabupaten Pasaman Barat.

\begin{tabular}{|c|c|c|c|c|c|}
\hline \multirow[b]{2}{*}{ No } & \multirow[b]{2}{*}{ Status P dan K } & \multirow{2}{*}{$\begin{array}{c}\text { Kebutuhan pupuk } \\
\text { SP } 36 \\
\text { dan } \mathrm{Kcl} \mathrm{kg/ha} \\
\end{array}$} & \multirow[b]{2}{*}{ Kecamatan } & \multicolumn{2}{|c|}{ luas } \\
\hline & & & & $\mathrm{Ha}$ & $\%$ \\
\hline \multirow{4}{*}{1} & & $\mathrm{SP} 36=90 \mathrm{~kg}$ & Pasaman & 212,8 & \\
\hline & P-tinggi dan K-tinggi & $\mathrm{Kcl}=0 \mathrm{~kg}$ & Luhak Nan Duo & 664,8 & \\
\hline & & & Kinali & 1668,3 & \\
\hline & & Jumlah & & 2545,9 & 33,0 \\
\hline \multirow{3}{*}{2} & & $\mathrm{SP} 36=90 \mathrm{~kg} / \mathrm{ha}$ & Pasaman & 320,5 & \\
\hline & P-tinggi dan K-sedang & $\mathrm{Kcl}=50 \mathrm{~kg} / \mathrm{ha}$ & Luhak Nan Duo & 908,2 & \\
\hline & & & Kinali & 1222,9 & \\
\hline \multirow{5}{*}{3} & & Jumlah & & 2451,6 & 31,8 \\
\hline & & SP $36=90 \mathrm{~kg}$ & Pasaman & 245,5 & \\
\hline & P-tinggi dan K-rendah & $\mathrm{Kcl}=250 \mathrm{~kg}$ & Luhak Nan Duo & 108,5 & \\
\hline & & & Kinali & 0,0 & \\
\hline & & Jumlah & & 354,0 & 4,6 \\
\hline \multirow{4}{*}{4} & & SP $36=250 \mathrm{~kg}$ & Pasaman & 67,7 & \\
\hline & P-sedang dan K-rendah & $\mathrm{Kcl}=50 \mathrm{~kg}$ & Luhak Nan Duo & 54,9 & \\
\hline & & & Kinali & 1062,0 & \\
\hline & & Jumlah & & 1184,6 & 15,4 \\
\hline \multirow{4}{*}{5} & & $\mathrm{SP} 36=250 \mathrm{~kg}$ & Pasaman & 66,2 & \\
\hline & P-sedang dan K-tinggi & $\mathrm{Kcl}=0 \mathrm{~kg}$ & Luhak Nan Duo & 0,0 & \\
\hline & & & Kinali & 186,3 & \\
\hline & & Jumlah & & 252,5 & 3,3 \\
\hline \multirow{4}{*}{6} & & SP $36=250 \mathrm{~kg}$ & Pasaman & 50,4 & \\
\hline & P-sedang dan K-rendah & $\mathrm{Kcl}=250 \mathrm{~kg}$ & Luhak Nan Duo & 0,0 & \\
\hline & & & Kinali & 0,0 & \\
\hline & & Jumlah & & 50,4 & 0,6 \\
\hline \multirow{5}{*}{7} & & $\mathrm{SP} 36=250 \mathrm{~kg}$ & Pasaman & 0,0 & \\
\hline & P-rendah dan K-sedang & $\mathrm{Kcl}=250 \mathrm{~kg}$ & Luhak Nan Duo & 0,0 & \\
\hline & & & Kinali & 863,2 & \\
\hline & & Jumlah & & 863,2 & 11,3 \\
\hline & & Total & & 7702,2 & 100 \\
\hline
\end{tabular}


serangan hama dan penyakit dan lain-lain. (Poerwowidodo, 1992).

Lahan dengan K-sedang, dibutuhkan pupuk Kcl sebanyak $50 \mathrm{~kg} / \mathrm{ha}$. Lahan dengan kandungan K-rendah membutuhkan pupuk $\mathrm{Kcl}$ sebanyak $250 \mathrm{~kg} / \mathrm{ha}$. Jumlah ini dapat diturunkan bila dilakukan tindakan-tindakan konservasi seperti melakukan persiapan lahan tanpa olah tanah (TOT), pengembalian sisa panen ke lapangan, penambahan pupuk organik dan pembuatan terasering pada lahanlahan yang miring. (Tabel 5).

\section{KESIMPULAN}

Dari hasil pegkajian dapat diambil beberapa kesimpulan antara lain :

1. Dari 7702.2 ha daerah pengkajian ternyata lahan yang mengandung $\mathrm{P}$ dengan kriteria tinggi 5351.5 ha $(69,4 \%)$, P kriteria sedang 1487,5 ha $(19,3 \%)$, dan P dengan kriteria rendah 863,2 ha $(11.2 \%)$. Lahan dengan kandungan K tinggi 2798,4 ha $(36,3 \%)$, $\mathrm{K}$ sedang 4499,4 ha $(58,4 \%)$ dan $\mathrm{K}$ rendah 404,4 ha $(5,2 \%)$

2. Kebutuhan pupuk SP36 pada lahan dengan kandungan $\mathrm{P}$ tinggi, sedang, dan rendah berturut turut $90 \mathrm{Kg} / \mathrm{ha}, 250$ $\mathrm{Kg} / \mathrm{ha}$, dan $500 \mathrm{Kg} / \mathrm{ha}$

3. Kebutuhan pupuk kcl pada lahan dengan kandumngan $\mathrm{K}$ tinggi, sedang, dan rendah adalah $0 \mathrm{Kg} / \mathrm{ha}, 50 \mathrm{Kg} / \mathrm{ha}$, dan $250 \mathrm{Kg} / \mathrm{ha}$

4. Rekomendasi kebutuhan pupuk SP36 dan kcl berdasarkan status hara P dan $\mathrm{K}$ dengan interpretasi hasil 4,5 ton jagung pipilan kering/ ha ( k.a 14\%) yang setara denga produksi jagung 8,0 ton pipilan kering panen /ha (k.a 25\%)

Daftar Pustaka

Bappeda Tingkat II Pasaman, 1999. Pasaman Dalam Angka. Kerjasama Bappeda Tk II Pasaman Dan Kantor Statistik Kabupaten Pasaman.

2000. Pasaman

Dalam Angka. Kerjasama Bappeda
Tk II Pasaman Dan Kantor Statistik. Kabupaten Pasaman.

2001. Pasaman

Dalam Angka. Kerjasama Bappeda Tk II Pasaman Dan Kantor Statistik. Kabupaten Pasaman.

2002. Pasaman

Dalam Angka. Kerjasama Bappeda Tk II Pasaman Dan Kantor Statistik. Kabupaten Pasaman.

2003. Pasaman

Dalam Angka. Kerjasama Bappeda Tk II Pasaman Dan Kantor Statistik. Kabupaten Pasaman.

Bappeda Tingkat II Pasaman Barat, 2003.

Pasaman Barat Dalam Angka. Kerjasama Bappeda Tk II Pasaman

Barat Dan Kantor Statistik Kabupaten Pasaman Barat.

Buckman, H.C. And N.C. Brady, 1964. The Nature And Properties Of Soil. The Mc Millan Co. N.Y.

Dinas Pertanian Dan Holtikultura Propinsi Sumatera Barat, 2004. Program Pengembangan Swasembada Jagung Di Propinsi Sumatera Barat.

Forth, 1988. Dasar-Dasar Ilmu Tanah.

Diterjemahkan Oleh Endah Dwi

Purbayanti ; Dwi Retno

Lukiwati Rahayuning Tri Mulatsih Dan

Editor: Andani B Hudoyono. Fakultas

Peternakan Universitas Diponegoro.

Gajah Mada University Press.

Oldeman, L.R, Irsal Las and S.N darwis, 1979.

An Agroclimatic of Sumatera. Dengan

Ringkasan Peta Agroklimat Sumatera.

Contribution. Number 62. Central

Research Institute For Agriculture

Bogor, Indonesia

Puslitbangtan, 2002. Inovasi Teknologi

Jagung. Menjawab Tantangan

Ketahanan Pangan Nasional.

Puslitbangtan. Bogor.

Poerwowidodo, 1992. Telaah Kesuburan Tanah. PT. Angkasa Bandung

Soepardi, G. 1974. Sifat Dan Ciri Tanah. Departemen Ilmu-Ilmu Tanah. Fakultas Pertanian Institute Pertanian Bogor. 